\title{
Layer, island and dendrite crystallizations of amorphous films as analogs of Frank-van der Merwe, Volmer-Weber and Stranski-Krastanov growth modes
}

\author{
A.G.Bagmut \\ National Technical University "Kharkiv Polytechnic Institute", \\ 2 Kyrpychova Str., 61002 Kharkiv, Ukraine
}

Received September 4, 2018

\begin{abstract}
Electron-microscope investigations "in situ", concerning the crystallization of amorphous films, are systematized. Based on the analysis of the structure and morphology of crystals growing in amorphous films as a result of electron beam influence, a quantitative interpretation of layer polymorphic crystallization (LPC), island polymorphic crystallization (IPC) and dendrite polymorphic crystallization (DPC) is given. For each crystallization mode the parameter of dimensionless relative length $\delta_{0}$, equal to the ratio of the characteristic length to the value, characterizing the size of the unit cell of the crystal, was respectively assigned. Based on the video recording of the process, the kinetic curves of LPC, IPC and DPC are constructed. LPC $\left(\mathrm{Cr}_{2} \mathrm{O}_{3}, \mathrm{~V}_{2} \mathrm{O}_{3}, \mathrm{Sb}_{2} \mathrm{~S}_{3}\right.$, Se and others $)$ is regarded as morphological analog of Frank-van der Merwe (FM) growth mode of a crystal from the vapor phase. In the case of LPC in the zone of observation in amorphous film grows a single flat crystal. By analogy with FM growth mode an energy criterion of the LPC can be written as $\sigma_{a} \geq \sigma_{c}+\sigma_{a c}+\varepsilon_{d}$, where $\sigma_{a}$ is the free energy of the amorphous phase-vacuum interface, $\sigma_{c}$ is the free energy of the crystalline phase-vacuum interface, $\sigma_{a c}$ is the free energy of the amorphous-crystalline phase interface, and $\varepsilon_{d}$ is the energy of deformation of the growing crystalline layer. For LPS the quadratic dependence of the fraction of the crystalline phase $x$ on time $t$ takes place and $\delta_{0} \sim 2500-4700$. IPC $\left(\mathrm{Al}_{2} \mathrm{O}_{3}\right.$, $\mathrm{ZrO}_{2}, \mathrm{Ni}, \mathrm{Re}$ and others) is regarded as morphological analog of Volmer-Weber growth mode of a crystal from the vapor phase. In the case of IPC in the zone of observation in amorphous film grows a lot of small disoriented crystals. By analogy with VW growth mode an energy criterion of the IPC can be written as $\sigma_{a} \leq \sigma_{c}+\sigma_{a c}+\varepsilon_{d}$. For IPS the exponential dependence of $x(t)$ takes place and $\delta_{0} \sim 100-900$. DPC (films of Fe-C, $\mathrm{HfO}_{2}$ ) is regarded as morphological analog of Stranski-Krastanov growth mode of a crystal from the vapor phase. A characteristic sign of DPC is the formation of dendrite branches along the sides of a flat single crystal. For DPC the quadratic dependence of $x(t)$ takes place and $\delta_{0} \sim 3900$.
\end{abstract}

Keywords: kinetic of crystallization, growth modes, in situ TEM, relative length, video recording.

Систематизированы электронно-микроскопические исследования "in situ", касающиеся кристаллизации аморфных пленок. Основываясь на анализе структуры и морфологии кристаллов, растущих в аморфных пленках в результате воздействия электронного луча, дана количественная трактовка слоевой полиморфной кристаллизации $(\mathrm{CПК),} \mathrm{островковой} \mathrm{полиморфной} \mathrm{кристаллизации} \mathrm{(ОПК)} \mathrm{и} \mathrm{дендритной} \mathrm{полиморфной}$ кристаллизации (ДПК). Для каждого типа кристаллизации определен безразмерный параметр относительной длины $\delta_{0}$, равный отношению характеристической длины $\kappa$ величине, связанной с размером элементарной ячейки кристалла. На основе видео 
регистрации процесса построены кинетические кривые СПК, ОПК и ДПК. СПК $\left(\mathrm{Cr}_{2} \mathrm{O}_{3}\right.$, $\mathrm{V}_{2} \mathrm{O}_{3}, \mathrm{Sb}_{2} \mathrm{~S}_{3}$, Se и др.) рассматривается как морфологический аналог механизма роста Франка-ван-дер-Мерве (ФМ) при росте кристалла из паровой фазы. В этом случае в зоне наблюдения в аморфной пленке растет одиночный плоский кристалл. По аналогии с механизмом роста ФМ энергетический критерий СПК может быть записан как $\sigma_{a} \geq \sigma_{c}+\sigma_{a c}+\varepsilon_{d}$, где $\sigma_{a}$ есть свободная энергия границы раздела аморфная фаза вакуум, $\sigma_{a c}-$ свободная энергия границы раздела аморфная фаза - кристалл, $\sigma_{c}-$ свободная энергия границы раздела кристалл - вакуум и $\sigma_{d}$ - энергия деформации растущего кристаллического слоя. Для СПК выполняется квадратичная зависимость доли кристаллической фазы $x$ от времени $t$ и $\delta_{0} \sim 2500-4700$. OПК $\left(\mathrm{Al}_{2} \mathrm{O}_{3}, \mathrm{ZrO}_{2}, \mathrm{Ni}, \mathrm{Re}\right.$ и др.) рассматривается как морфологический аналог механизма роста Фольмера-Вебера при росте кристаллов из паровой фазы. По аналогии с механизмом роста ФМ энергетический критерий ОПК может быть записан как $\sigma_{a} \leq \sigma_{c}+\sigma_{a c}+\varepsilon_{d}$. В случае ОПК в зоне наблюдения в аморфной пленке растет множество мелких разориентированных кристаллов. Для ОПК выполняется экспоненциальная зависимость $x(t)$ и $\delta_{0} \sim 100-900$. ДПК (пленки $\mathrm{Fe}-\mathrm{C}, \mathrm{HfO}_{2}$ ) рассматривается как морфологический аналог механизма роста Странского-Крастанова при росте кристаллов из паровой фазы. Характерным признаком ДПК является образование дендритных ветвей на сторонах плоского монокристалла. Для ДПК выполняется квадратичная зависимость $x(t)$ и $\delta_{0} \sim 3900$.

Шарова, острівцева та дендритна кристалізація аморфних плівок як аналоги механизмів росту Франка-ван-дер-Мерве, Фольмера-Вебера і Странського-Крастанова. О.Г.Багмут.

Систематизовано електронно-мікроскопічні дослідження "in situ", що стосуються кристалізації аморфних плівок. Грунтуючись на аналізі структури та морфології кристалів, що ростуть в аморфних плівках у результаті впливу електронного променя, дано кількісне трактування шарової поліморфної кристалізації (ШПК), острівцевої поліморфної кристалізації (ОПК) та дендритної поліморфної кристалізації (ДПК). Для кожного типу кристалізації визначено безрозмірний параметр відносної довжини $\delta_{0}$, який дорівнюе відношенню характеристичної довжини до величини, яка пов'язана 3 розміром елементарної комірки кристала. На основі відео реєстрації процесу побудовані кінетичні криві ШПК, ОПК і ДПК. ШПК $\left(\mathrm{Cr}_{2} \mathrm{O}_{3}, \mathrm{~V}_{2} \mathrm{O}_{3}, \mathrm{Sb}_{2} \mathrm{~S}_{3}\right.$, Se та ін.) розглядається як морфологічний аналог механізму росту Франка-ван-дер-Мерве (ФМ) при зростанні кристала з парової фази. У цьому випадку у зоні спостереження в аморфній плівці зростає одиночний плоский кристал. За аналогією з механізмом зростання ФМ енергетичний критерій ШПК може бути записаний як $\sigma_{a} \geq \sigma_{c}+\sigma_{a c}+\varepsilon_{d}$, де $\sigma_{a}$ є вільна енергія поверхні розділу аморфна фаза - вакуум, $\sigma_{a c}-$ вільна енергія поверхні розділу аморфна фаза - кристал, $\sigma_{c}$ - вільна енергія поверхні розділу кристал вакуум і $\sigma_{d}$ - енергія деформації зростаючого кристалічного шару. Для ШПК виконується квадратична залежність частки кристалічної фази $x$ від часу $t$ i $\delta_{0} \sim 2500-$ 4700. ОПК $\left(\mathrm{Al}_{2} \mathrm{O}_{3}, \mathrm{ZrO}_{2}\right.$, Ni, $\mathrm{Re}$ та ін.) розглядається як морфологічний аналог механізму росту Фольмера-Вебера при зростанні кристалів з парової фази. За аналогією 3 механізмом зростання ФМ енергетичний критерій ОПК може бути записаний як $\sigma_{a}$ $\leq \sigma_{c}+\sigma_{a c}+\varepsilon_{d}$. У разі ОПК у зоні спостереження в аморфній плівці росте безліч дрібних разорієнтованих кристалів. Для ОПК виконується експоненціальна залежність $x(t)$ і $\delta_{0} \sim 100-900$. ДПК (плівки $\mathrm{Fe}-\mathrm{C}, \mathrm{HfO}_{2}$ ) розглядається як морфологічний аналог механізму росту Странського-Крастанова при зростанні кристалів з парової фази. Характерною ознакою ДПК є утворення дендритних гілок на сторонах плоского монокристала. Для ДПК виконується квадратична залежність $x(t)$ і $\delta_{0} \sim 3900$.

\section{Introduction}

The classical scheme of the formation of a crystalline layer upon condensation of a vapor stream on a substrate (transformations vapor - crystal) suggests the following growth mode of a film [1]. The Frankvan der Merwe (FM) growth mode (layer-bylayer growth). According to Bauer's criterion [2], this mode is realized when the inequality $\gamma_{s} \geq \gamma_{f}+\gamma_{s f}$ is satisfied. Here $\gamma_{s}$, $\gamma_{f}, \gamma_{s f}$ are the surface energy of substrate, film, and interphase energy between the film and substrate, respectively. The VolmerWeber (VW) growth mode (island growth). This mode is realized when the opposite inequality $\gamma_{s} \leq \gamma_{f}+\gamma_{s f}$ is satisfied. The Stranski-Krastanov (SK) growth mode (layer-plusisland growth). This mode is realized initially when $\gamma_{s} \geq \gamma_{f}+\gamma_{s f}$. Then, after critical thickness, $\gamma_{s} \leq \gamma_{f}+\gamma_{s f}$ (Table). The above is valid 
Table. Comparison of phase transformations vapor-crystal at films growth and amorphous phase - crystal at films crystallization*

\begin{tabular}{|c|c|c|c|c|c|c|}
\hline \multicolumn{3}{|c|}{ Transformation vapor - crystal } & \multicolumn{4}{|c|}{ Transformation amorphous phase - crystal } \\
\hline $\begin{array}{c}\text { Growth } \\
\text { mode }[1,2]\end{array}$ & Mechanism & Condition & $\begin{array}{c}\text { Crystallization } \\
\text { type }[5,6]\end{array}$ & Mechanism & Condition & $\begin{array}{l}\text { Relative } \\
\text { length } \delta_{0}\end{array}$ \\
\hline FM & & $\gamma_{\mathrm{s}} \geq \gamma_{\mathrm{f}}+\gamma_{\mathrm{sf}}$ & LPC & & $\sigma_{\mathrm{a}} \geq \sigma_{\mathrm{c}}+\sigma_{\mathrm{ac}}+\varepsilon_{\mathrm{d}}$ & $2500-4700$ \\
\hline VW & 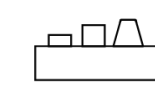 & $\gamma_{\mathrm{s}} \leq \gamma_{\mathrm{f}}+\gamma_{\mathrm{sf}}$ & IPC & $\begin{array}{l}\mathbb{O} \mathbb{0} \\
\mathbb{0} \mathbb{0}\end{array}$ & $\sigma_{\mathrm{a}} \leq \sigma_{\mathrm{c}}+\sigma_{\mathrm{ac}}+\varepsilon_{\mathrm{d}}$ & $100-900$ \\
\hline SK & 回 & $\begin{array}{c}\text { Initially } \\
\gamma_{\mathrm{s}} \geq \gamma_{\mathrm{f}}+\gamma_{\mathrm{sf}}, \\
\text { then } \\
\gamma_{\mathrm{s}} \leq \gamma_{\mathrm{f}}+\gamma_{\mathrm{sf}}\end{array}$ & DPC & $\sum_{-\mathbb{4}}^{\mathbb{4}}$ & $\begin{array}{c}\text { Initially } \\
\sigma_{\mathrm{a}} \geq \sigma_{\mathrm{c}}+\sigma_{\mathrm{ac}}+\varepsilon_{\mathrm{d}}, \\
\text { then } \\
\sigma_{\mathrm{a}} \leq \sigma_{\mathrm{c}}+\sigma_{\mathrm{ac}}+\varepsilon_{\mathrm{d}}\end{array}$ & $\sim 3900$ \\
\hline
\end{tabular}

"FM is the Frank-van der Merwe growth mode, VW is the Volmer-Weber growth mode, SK is the Stranski-Krastanov growth mode. LPC is the layer polymorphous crystallization, IPC is the island polymorphous crystallization, DPC is the dendrite polymorphous crystallization. $\gamma_{s}, \gamma_{f}, \gamma_{s f}$ are the surface energy of substrate, film and interphase energy between film and substrate, respectively. $\sigma_{a}$, $\sigma_{c}, \sigma_{a c}$ are the surface energy of amorphous phase-vacuum interface, surface energy of the crystalline phase-vacuum interface and surface energy of the amorphous-crystalline phase interface, respectively. $\varepsilon_{d}$ is the energy of deformation of the growing crystalline layer.

if no chemical reactions, alloying or other changes of the surfaces occur during film growth [2]. Descriptive experimental illustration of this growth mode is given in [3, 4].

The phenomenological scheme of the formation of a crystalline layer upon crystallization of amorphous films (transformations amorphous phase - crystal) suggests the following types [5,6]. Layer polymorphous crystallization (LPC), which represents an analog of the FM growth mode. By analogy with the above-mentioned Bauer criterion, this type can be realized when the inequality $\sigma_{a} \geq \sigma_{c}+\sigma_{a c}+\varepsilon_{d}$ is satisfied. Here $\sigma_{a}, \sigma_{c}, \sigma_{a c}$ are the surface energy of amorphous phase-vacuum interface, of the crystalline phase-vacuum interface and surface energy of the amorphous-crystalline phase interface, respectively. $\varepsilon_{d}$ is the energy of deformation of the growing crystalline layer. Island polymorphous crystallization (IPC), which represents an analog of the VW growth mode. This type is realized when the opposite inequality $\sigma_{a} \leq \sigma_{c}+$ $\sigma_{a c}+\varepsilon_{d}$ is satisfied. Dendrite polymorphous crystallization (DPC), which represents an analog of the SK growth mode. This type is realized when initially $\sigma_{a} \geq \sigma_{c}+\sigma_{a c}+\varepsilon_{d}$, and after critical dimension of a crystal, when $\sigma_{a} \leq \sigma_{c}+\sigma_{a c}+\varepsilon_{d}$ (Table 1 ).

A sufficiently complete analysis and comparison of the morphological community of transformations vapor - crystal at films growth and amorphous phase - crystal at films crystallization are not available now. So, the aim of this work was to give an overview of the main types of crystallization of amorphous films with an emphasis on electron-beam crystallization "in situ" of oxides, obtained predominantly by laser evaporation.

\section{Experimental}

Amorphous films were prepared by the thermal deposition of material in vacuum, pulsed laser deposition in an oxygen atmosphere and by ion-plasma deposition in argon-oxygen atmosphere on substrates at room temperature. $\mathrm{KCl}$ crystals, cleaved in air along the (001) planes, served as substrates. After deposition and depressurization of the chamber, the films were separated from the substrates in distilled water and transferred to the object grids for the electron microscopic studies. Structural analysis was performed by electron diffraction and transmission electron microscopy on EM-100L and PEM-100-01 electron mi- 


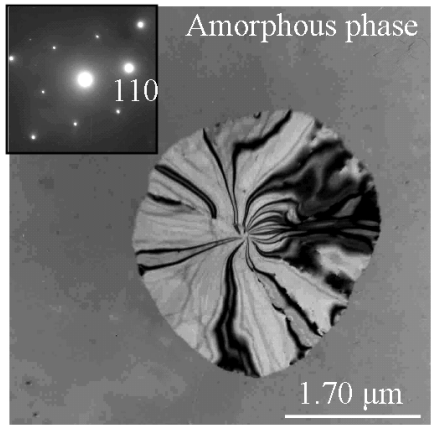

a)

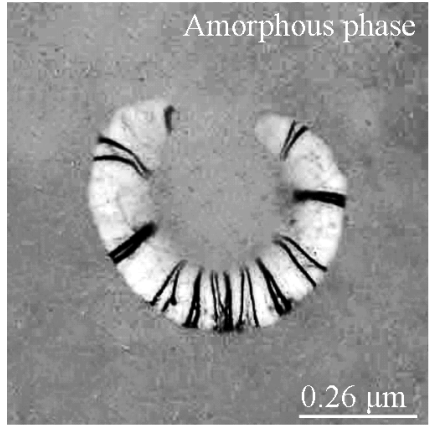

b)

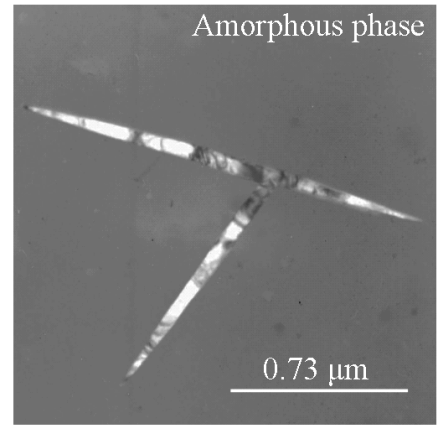

c)

Fig. 1. The basic morphological forms of layer polymorphous crystallization (LPC): disk-shaped (a), sickle-shaped (b) and needle-shaped (c) crystals in amorphous film of $\mathrm{Cr}_{2} \mathrm{O}_{3}$. The inset in the left upper corner corresponds to selected area electron diffraction (SAED) pattern of a disk-shaped crystal.

croscopes operated at an accelerating voltage of $100 \mathrm{kV}$. The thickness of the films varied in the range from 25 to $30 \mathrm{~nm}$. The crystallization of a film was initiated by electron beam irradiation in the column of a transmission electron microscope. The crystallization of the local area of the amorphous film was initiated and maintained all the time by an electron beam at a beam current of $\sim 20 \mu \mathrm{A}$. It was not a consequence of the appearance of a crystal nucleus, since it did not continue on its own (as is the case, for example, in supercooled liquids) after the termination of the electron-beam action. The crystallization rate was set by varying the electron current density $j$ through the sample, which was 1.16.5 $\mathrm{A} \cdot \mathrm{mm}^{-2}$, depending on the beam focusing. The film crystallization process was recorded from the screen of an electron microscope on a Canon Power Shot G15 camera in the video record mode at a frame rate of $30 \mathrm{~s}^{-1}$. The experimental details are presented in [7].

Quantification of the crystallization type (LPC or IPC) was carried out on the basis of the value of relative length $\delta_{0}$, defined as

$$
\delta_{0}=\frac{D_{0}}{a_{0}}
$$

in the case of LPC, and as

$$
\delta_{0}=\frac{D_{0}}{\Omega^{1 / 3}}
$$

in the case of IPC. Characteristic unit length $D_{0}$ is the crystal size at time $t_{0}$, after which the volume of the amorphous phase decreases by a factor of $e=2.718$. $a_{0}$ in expression (1) is a cell parameter of a growing crystal. $\Omega$ in expression (2) is the volume of the unit cell of a growing crystal. The difference in the determination of $\delta_{0}$ is due to the fact, that in the case of LPC a single crystal (with a cell parameter $a_{0}$ ) is formed in the investigated region, and in the case of IPC a polycrystalline film whose grains have different orientations [8, 9].

\section{Results and discussion}

3.1. Layer polymorphous crystallization as morphological analog of the Frank-van der Merwe growth mode

In the case of a LPC crystalline phase is initially formed in a thin near surface layer and its composition coincides with that of the initial amorphous phase. The velocity of propagation of the crystallization front in the tangential direction $\left(v_{\tau}\right)$ significantly exceeds the velocity of crystallization front propagation along the normal to the film surface $\left(v_{n}\right)$. The crystalline layer appears as "spreading" over the film surface.

The LPC type is inherent to a considerable extent in semiconductors ( $\mathrm{Se}, \mathrm{Te}, \mathrm{Sb}$ $[10,11], \mathrm{Sb}_{2} \mathrm{~S}_{3}[12]$, etc. $)$ and oxides $\left(\mathrm{ReO}_{3}\right.$ [12], $\mathrm{Cr}_{2} \mathrm{O}_{3}$ [13], $\mathrm{V}_{2} \mathrm{O}_{3}$ [14], $\mathrm{Fe}_{2} \mathrm{O}_{3}$ [15] etc.). In amorphous $\mathrm{Cr}_{2} \mathrm{O}_{3}$ films the main morphological forms (disk-shaped, sickle-shaped and needle-shaped crystals) of layer polymorphous crystallization are observed [9, 16]. In this work, the main morphological forms of LPC in $\mathrm{Cr}_{2} \mathrm{O}_{3}$ are shown in Fig. 1 . This is disk-shaped (a), sickle-shaped (b) and needle-shaped (c) crystals. Each of these forms has its own kinetics of the development.

Disk-shaped crystals grow with a constant speed $v$ and unchanged morphology (Fig. 2a, 2b, 2c). The dependence of the ra- 


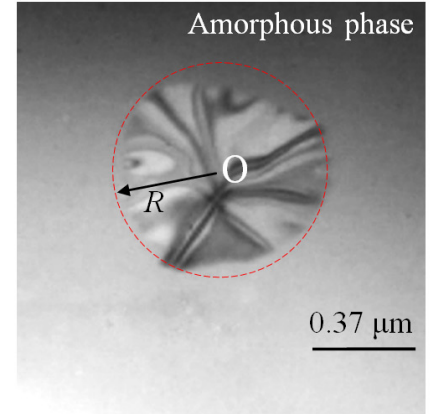

a)

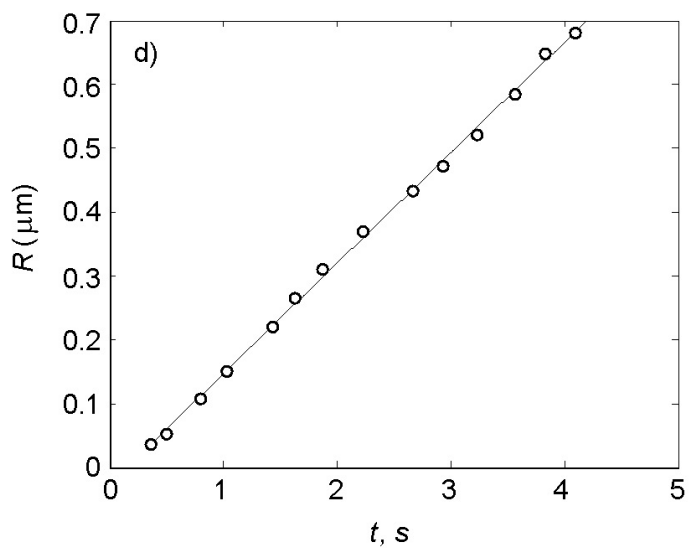

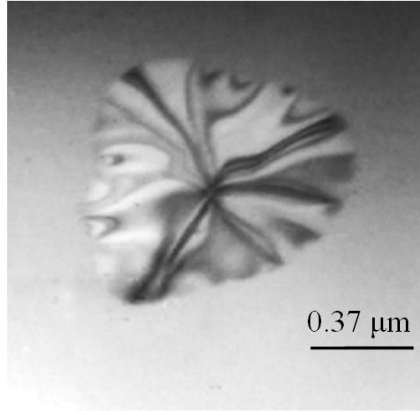

b)

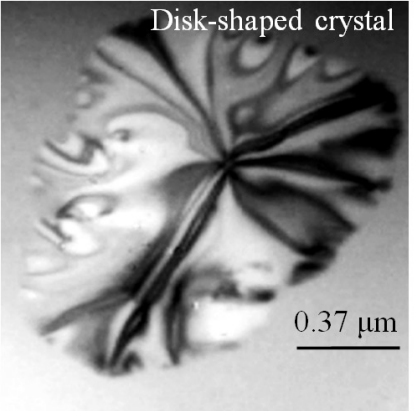

c)

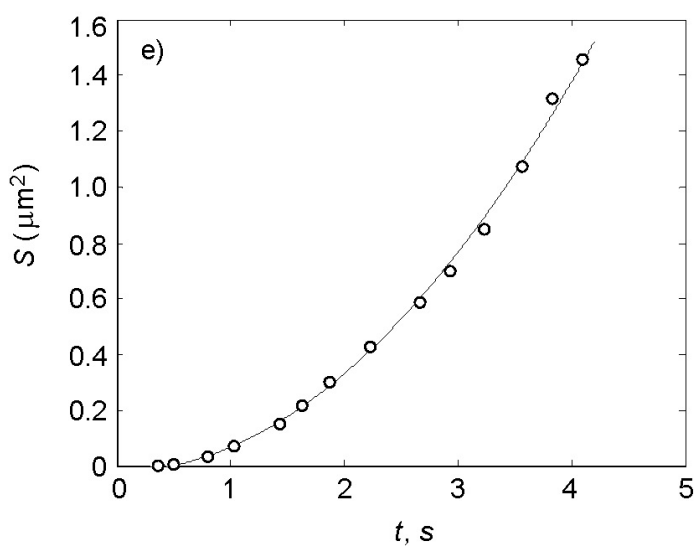

Fig. 2. LPC. Kinetic of growth (with the rate $v=0.173 \mu \mathrm{m} \cdot \mathrm{s}^{-1}$ ) of a disk-shaped crystal in amorphous film of $\mathrm{Cr}_{2} \mathrm{O}_{3}$. Electron microphotographs correspond to the time moments $t$, which have passed from the beginning of the recording of the crystallization process: (a) $t=2.23 \mathrm{~s}$; (b) $t=$ $2.93 \mathrm{~s}$; (c) $t=3.83 \mathrm{~s}$. The dependences of the radius $R$ of the crystal (d) and of the area $S$ of the crystalline phase (e) on time $t$.

dius $R$ of the crystal and of the area $S$ of the crystalline phase on time $t$ are shown in Fig. 2d and 2e respectively. According to these kinetic curves, the speed of displacement of the crystallization front $v=R_{t}^{\prime}=$ $0.173 \mu \mathrm{m} \cdot \mathrm{s}^{-1}$. There is a quadratic dependence $S(t)$ (and consequently of the fraction of the crystallized region $x(t)): \quad S(t)=$ $0.0873 \cdot t^{2}\left(\mu \mathrm{m}^{2}\right)$. The area of the analyzed sample $S_{s}=2.9 \mu \mathrm{m}^{2}$. So, characteristic time (after which $x=0.632$ ) $t_{0}=4.58 \mathrm{~s}$ and characteristic length $D_{0}=1.58 \mu \mathrm{m}$. For a crystal of $\mathrm{Cr}_{2} \mathrm{O}_{3}$ with the [001] zone axis (Fig. 1a), the projection of the unit cell on the plane of the film is a rhomb with a side $a_{0}=0.496 \mathrm{~nm}$ and apex angle of $120^{\circ}$. In this case, according to (1), the relative length $\delta_{0}=3185$. It is comparable to the values $\delta_{0} \sim 4300-4700$ for the layer polymorphous crystallization of amorphous $\mathrm{V}_{2} \mathrm{O}_{3}$ films obtained by laser evaporation [8].

Sickle-shaped crystals grow with a variable rate $\mathrm{v}$ and with a changeable morphology (Fig. 3a, 3b, 3c). Fig. 3d shows the $R(t)$ curve for sickle-shaped (in the initial stages) crystal of $\mathrm{Cr}_{2} \mathrm{O}_{3}$ during electron beam crystallization of the film. According to this, at the initial stages (stages of the sickle and of the ring), there is a parabolic dependence $R(t) \sim t^{0.5}$. At the final stage of growth (stage of the disk), there is a linear dependence $R(t) \sim t$. At this stage the growth of the crystal occurs with a velocity $v_{I}=0.075 \mu \mathrm{m} \cdot \mathrm{s}^{-1}$. The kinetic curve $S(t)$ is shown in Fig. 3e. In part 1 (the sickleshaped stage) and in part 3 (disk stage) $S(t)$ $\sim t^{2}$ (in $S-t^{2}$ coordinates the experimental data are placed on straight lines). In part 2 (ring-shaped stage) the dependence $S(t)$ is more complex.

Needle-shaped crystals some time grow with a constant speed $v$ and with unchanged morphology (Fig. 4a, 4b). But during growth process on the lateral surface of a needle-shaped crystal is possible the formation of outgrowths (Fig. 4c). Fig. 4d shows the dependence of a crystal length $L$ and length of lateral outgrowths $h_{1}$ and $h_{2}$ on 


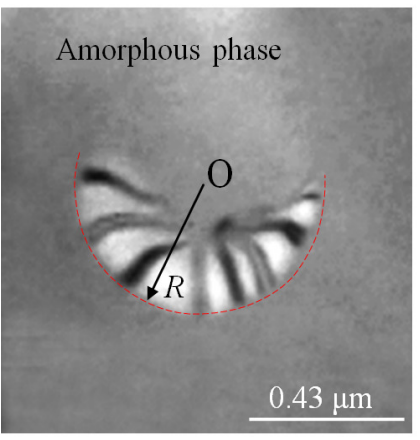

a)

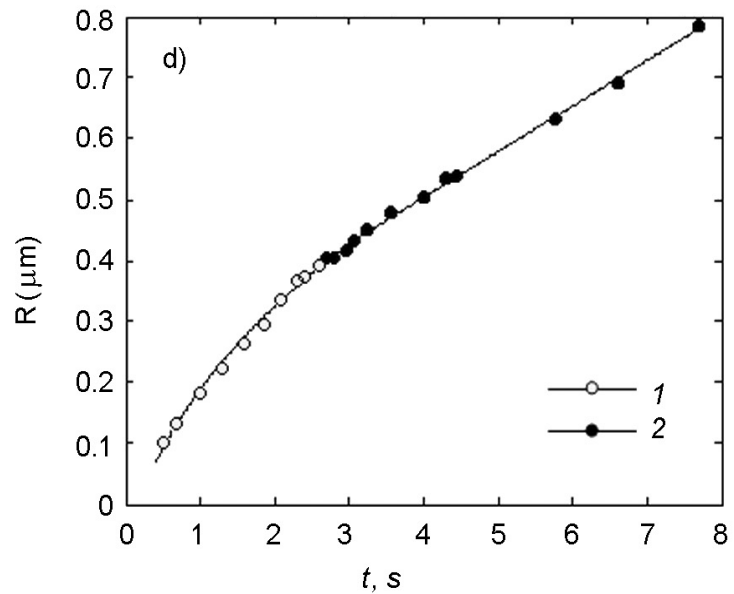

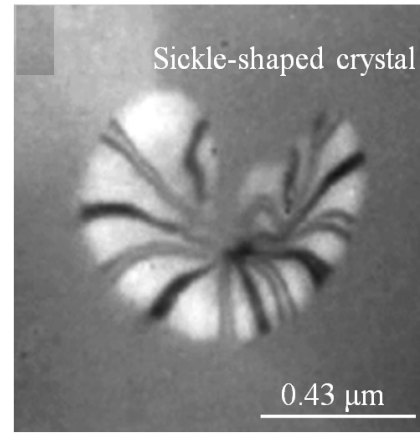

b)

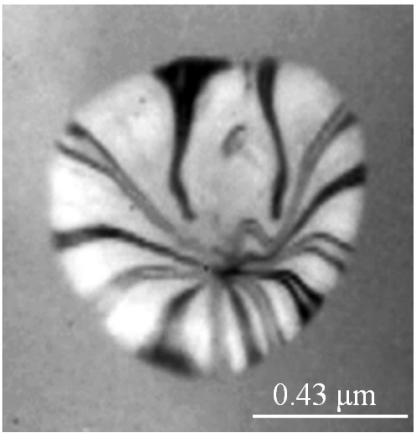

c)

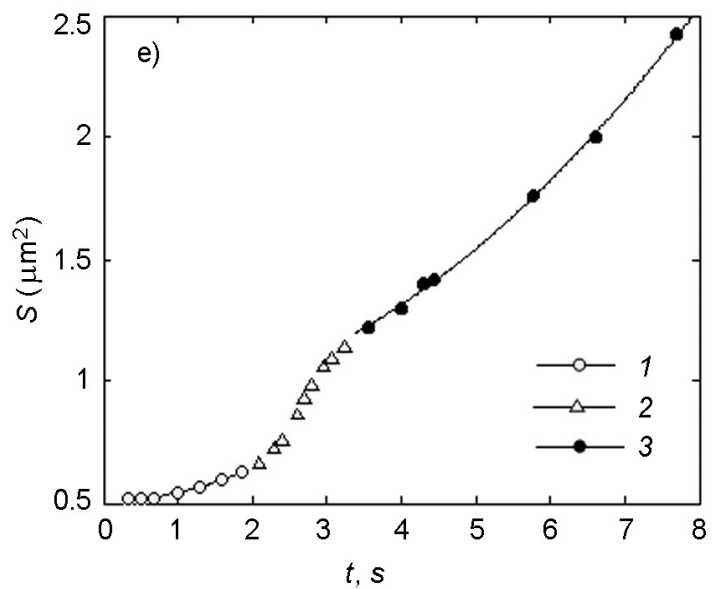

Fig. 3. Kinetic of growth of a sickle-shaped crystal in amorphous film of $\mathrm{Cr}_{2} \mathrm{O}_{3}$ (LPC). Electron microphotographs correspond to the time moments $t$, which have passed from the beginning of the recording of the crystallization process: (a) $t=2.10 \mathrm{~s}$; (b) $t=2.60 \mathrm{~s}$; (c) $t=3.07 \mathrm{~s}$. (d) The dependence of the arc radius $R$ of the crystallization front at time $t$. Region 1 - the sickle and ring stages, region 2 - the stage of the disk. (e) The dependence of the area $S$ of the crystalline phase on time $t$. Region 1 - the stage of the sickle, 2 - the stage of the ring, 3 - the stage of the disk.

time $t$. When outgrowth occurs on the lateral surface of the needle-shape crystal, the rate of the increasing of in $L$ decreases. The straight section of $L$ corresponds to the growth rate of a crystal length $v_{L}=$ $1.746 \mu \mathrm{m} \cdot \mathrm{s}^{-1}$, that is commensurate with the rate of growth of the lateral outgrowth $v_{h 1}=1.604 \mu \mathrm{m} \cdot \mathrm{s}^{-1}$ and $v_{h 2}=1.453 \mu \mathrm{m} \cdot \mathrm{s}^{-1}$. The dependence $S(t)$ is shown in Fig. 4e. A straight line (in coordinates $S(t)-t^{2}$ ) indicates that $S(t) \sim G_{S} t^{2}$ with the coefficient $G_{S}=0.105 \mu \mathrm{m}^{2} \cdot \mathrm{s}^{-2}$. When outgrowth occurs on the lateral surface of the needle-shape crystal, the rate of increasing of $S$ increases and the linear dependence than is not satisfied.

3.2. Island polymorphous crystallization as morphological analog of the VolmerWeber growth mode

In the case of IPC crystalline phase formed in a thin near surface layer and its composition coincides with that of the amorphous phase. The final stage of the process leads to the formation of a polycrystalline film (Fig. 5). Crystalline phase does not tend to eliminate the free surface of amorphous phase ("no wetting" condition). This type of reaction is inherent in the crystallization of some amorphous metals and oxides ( $\mathrm{Ni}, \mathrm{Re}$ [12], $\mathrm{Al}_{2} \mathrm{O}_{3}$ [5], $\mathrm{ZrO}_{2}$ [7], etc.).

Fig. 6 illustrates the kinetics of IPC of amorphous film of $\mathrm{ZrO}_{2}$. Electron micrographs corresponds to the time moments $t$, which have passed from the beginning of the recording of the crystallization process: (a) $t=28.63 \mathrm{~s}$; (b) $t=127.00 \mathrm{~s}$; (c) $t=$ $194.87 \mathrm{~s}$. The dependences of average diameter $D(t)$ of crystals are shown in Fig. $6 d$. The straight line was plotted by the data of $D$ measurements using the leastsquares technique. The average growth rate of crystals (that was determined from the slope of the line to abscissa) $v=$ $0.002 \mu \mathrm{m} \cdot \mathrm{s}^{-1}$. 


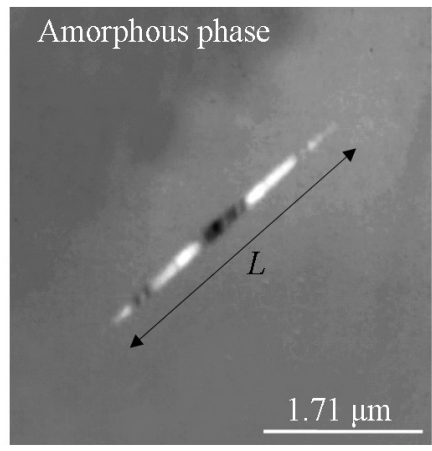

a)

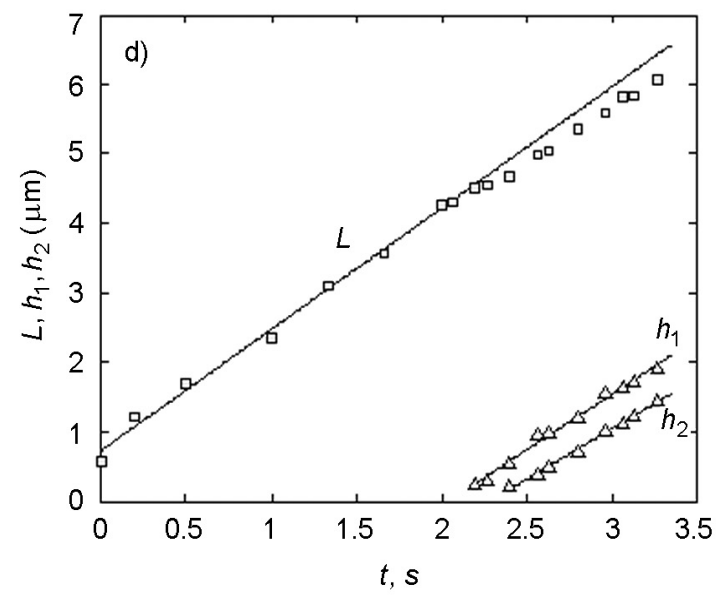

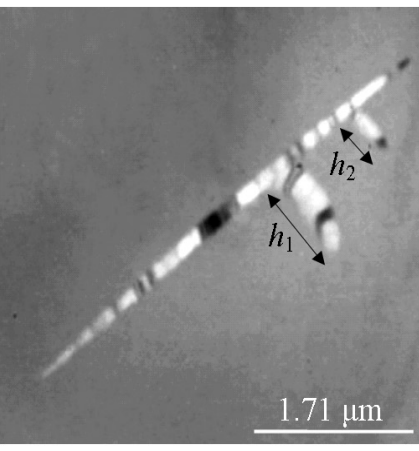

c)

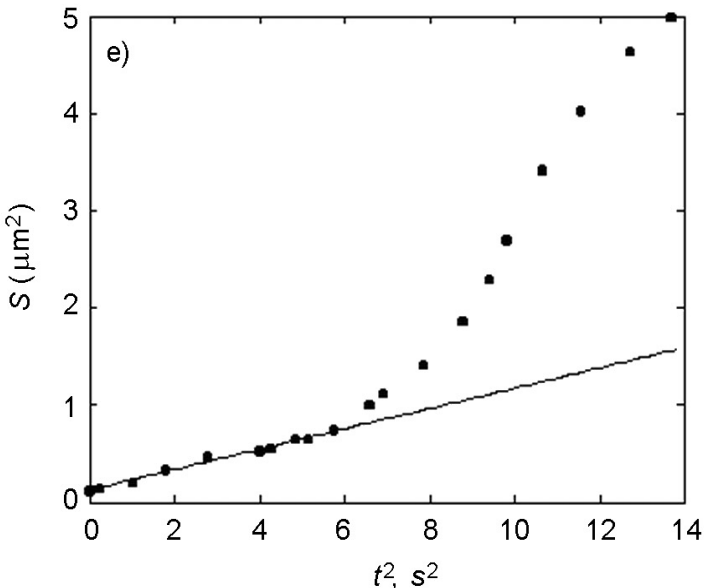

Fig. 4. Kinetic of growth of a needle-shaped crystal in amorphous film of $\mathrm{Cr}_{2} \mathrm{O}_{3}$ (LPC). Electron microphotographs corresponds to the time moments $t$, which have passed from the beginning of the recording of the crystallization process: (a) $t=1.33 \mathrm{~s}$; (b) $t=2.07 \mathrm{~s}$; (c) $t=2.63 \mathrm{~s}$. (d) The dependences of a crystal length $L$ and length of lateral outgrowths $h_{1}$ and $h_{2}$ on time $t$. (e) The dependence of the area $S$ of the crystalline phase on $t^{2}$.

The dependence $S(t)$ is shown in Fig. 6 e. The fact, that the crystallization curve in coordinates $\ln \left[-\ln \left(1-S / S_{s}\right)\right]-\ln t$ are straight line, indicates that occurs the Johnson-Mehl-Avrami-Kolmogorov (JMAK) equation $S=S_{s}\left[1-\exp \left(-n t^{k}\right)\right]$, where $k$ and $n$ are the kinetic parameters of crystallization [17]. According to [7] for $v=$ $0.002 \mu \mathrm{m} \cdot \mathrm{s}^{-1}$ kinetic parameter $k=1.3$ and $n=0.001$. So, characteristic time $t_{0}=n^{-1 / \mathrm{k}}$ $=203 \mathrm{~s}$ and characteristic length $D_{0}=v t_{0}=$ $0.41 \mu \mathrm{m}$. The volume of $\mathrm{ZrO}_{2}$ cubic sell $\Omega=$ $1.32 \cdot 10^{-10} \mu^{3}$. In this case, according to (2), the relative length $\delta_{0} \approx 805$. It is comparable to the values $\delta_{0} \sim 1000$ for the special case of IPC in amorphous film of $\mathrm{V}_{2} \mathrm{O}_{3}$ [8]. The smaller the grain size of the crystallized film, the smaller the dimensionless parameter $\delta_{0}$.

Thus, electron-beam crystallization of amorphous $\mathrm{ZrO}_{2}$ films, deposited by ionplasma sputtering (Fig. 5b), results to the formation of a highly disperse polycrystalline structure with $\delta_{0} \approx 100$ [7]. The charge and energy of ions in condensed on a substrate stream during ion-plasma and laser sputtering are different. Ion-plasma deposition creates a large density of defects (for example, color centers) in the surface layer of $\mathrm{KCl}$, which leads to a higher density of hidden crystallization centers in an amorphous $\mathrm{ZrO}_{2}$ film.

3.3. Dendrite polymorphous crystallization as morphological analog of the Stranski-Krastanov growth mode

DPC was observed in amorphous films of Fe-C [18], $\mathrm{V}-\mathrm{O}$ and $\mathrm{HfO}_{2}$ [12]. Phase transformation amorphous phase-dendrite $\mathrm{HfO}_{2}$ of a monoclinic modification accompanied by the formation of outgrowths (dendrite branches of the second and third order) on the lateral surface of the dendrite branches of the first order (Fig. 7). It should be considered as morphological analogue of SK growth mode of a crystal from the vapor 


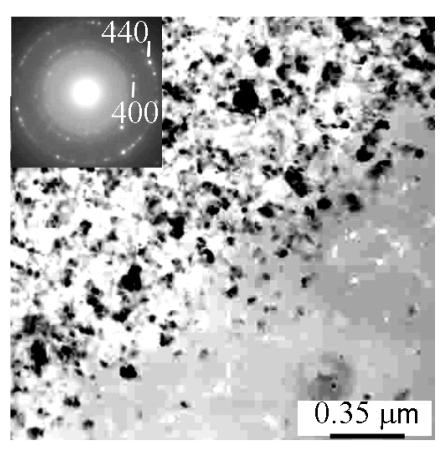

a)

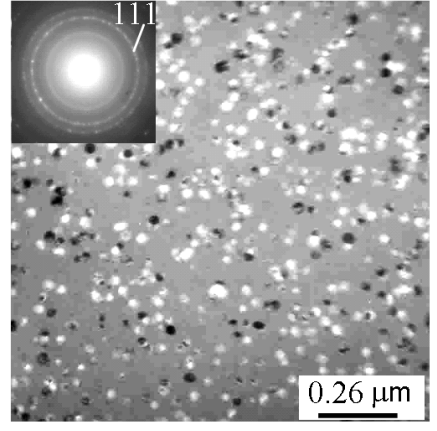

b)

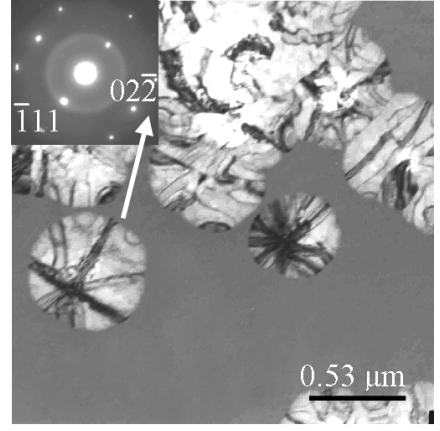

c)

Fig. 5. Island polymorphous crystallization (IPC) of amorphous films. Electron microscopic images of crystallizing films of $\mathrm{Al}_{2} \mathrm{O}_{3}$ (a) (laser evaporation), of $\mathrm{ZrO}_{2}$ (b) (ion-plasma evaporation), of $\mathrm{ZrO}_{2}$ (c) (laser evaporation). SAED patterns are shown in the upper left corner of the micrographs.

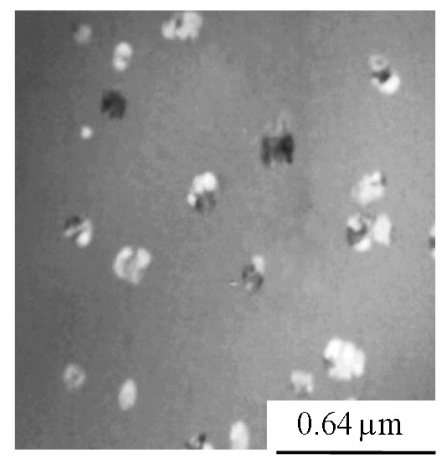

a)

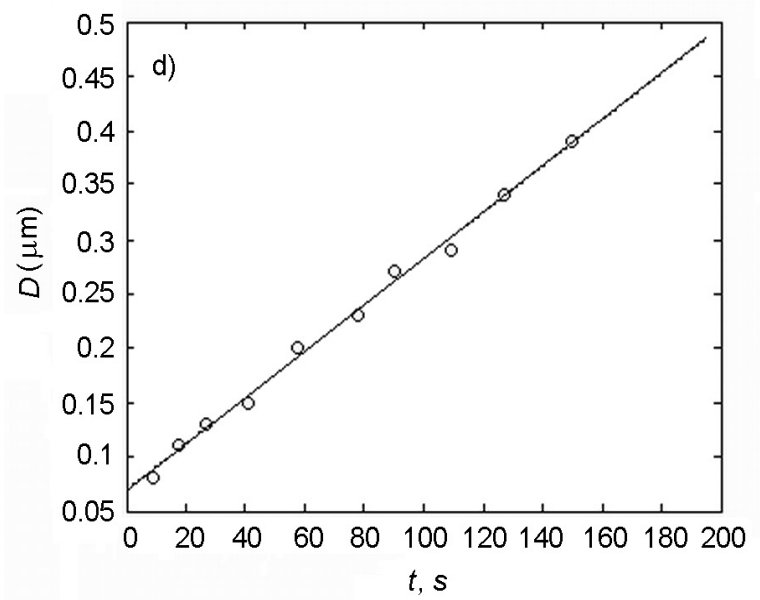

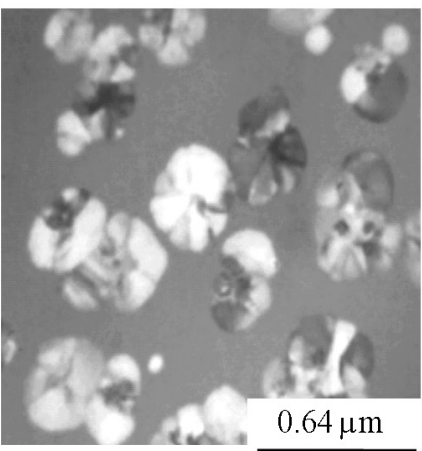

b)

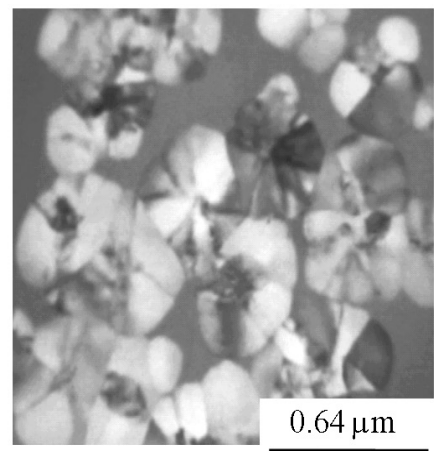

c)

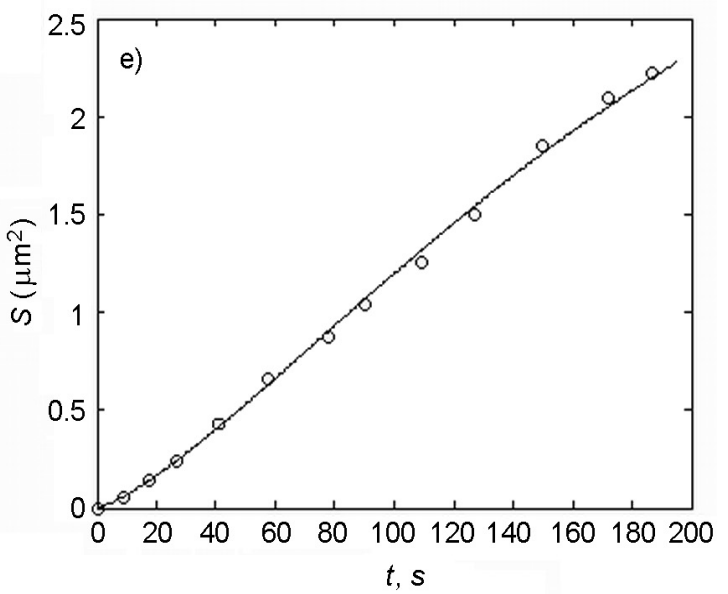

Fig. 6. Kinetic of crystals growth in amorphous film of $\mathrm{ZrO}_{2}$ (IPC). Electron microphotographs corresponds to the time moments $t$, which have passed from the beginning of the recording of the crystallization process: (a) $t=28.63 \mathrm{~s}$; (b) $t=127.00 \mathrm{~s}$; (c) $t=194.87 \mathrm{~s}$. (d) The dependence of the average diameter $\mathrm{D}$ of crystals on time $t$. (e) The dependence of the area $\mathrm{S}$ of the crystalline phase on time $t$.

phase [1]. The crystalline phase of $\mathrm{HfO}_{2}$ is denser than of amorphous one. Therefore a crystal, growing in amorphous film, is in the field of tensile stresses, which can initiate the growth of new crystals on the lateral surface of the already existing one.
Kinetic of dendrite growth in amorphous film of $\mathrm{HfO}_{2}$ are shown in Fig. 8. Electron microphotographs corresponds to the time moments $t$, which have passed from the beginning of the recording of the crystallization process: (a) $t=5.03 \mathrm{~s}$; (b) $t=$ 


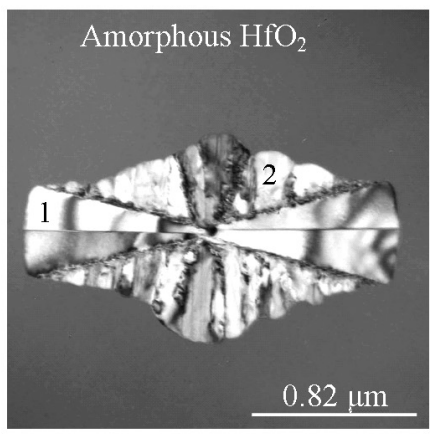

a)

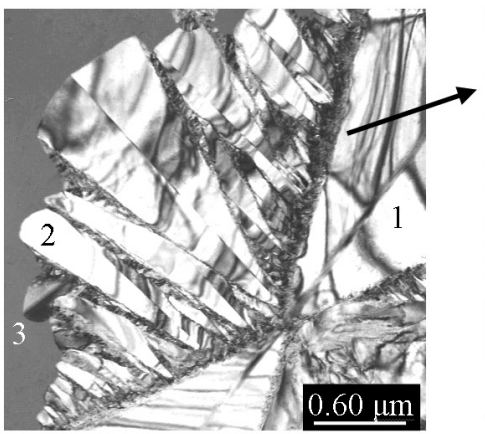

b)

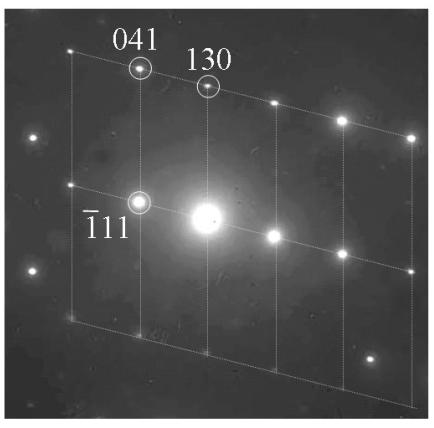

c)

Fig. 7. Dendrite polymorphous crystallization (DPC) of amorphous film of $\mathrm{HfO}_{2}$. (a) Electron microscope image of dendrite in amorphous film. (b) Geometric selection in a growing aggregate of $\mathrm{HfO}_{2}$ crystals. (c) SAED pattern from the dendrite branch of the first order. Numbers 1, 2, 3 marks the branches of the dendrite of the first, second and third order, respectively.

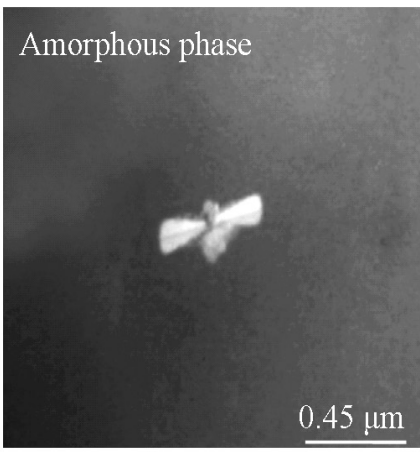

a)

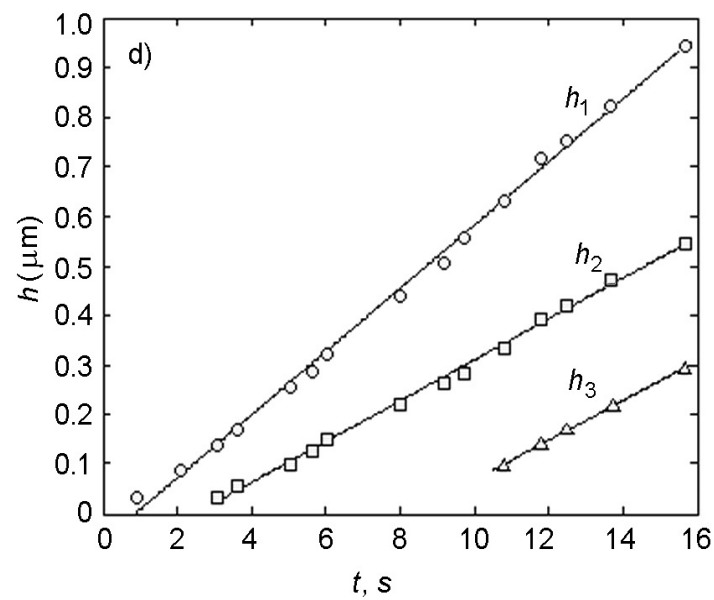

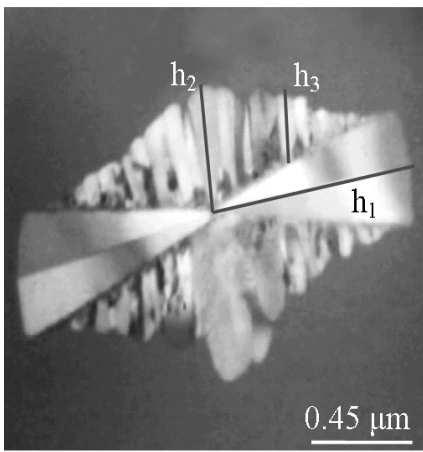

c)

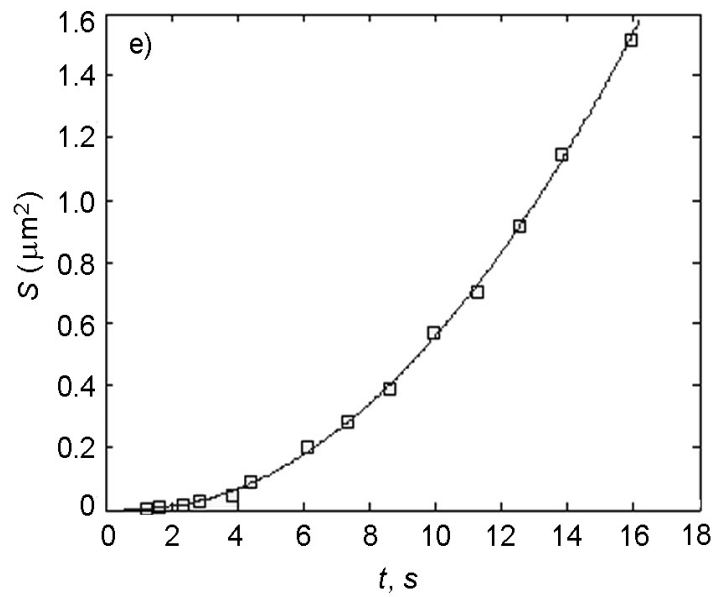

Fig. 8. Kinetic of dendrite growth in amorphous film of $\mathrm{HfO}_{2}$ (DPC). Electron microphotographs corresponds to the time moments $t$, which have passed from the beginning of the recording of the crystallization process: (a) $t=5.03 \mathrm{~s}$; (b) $t=10.77 \mathrm{~s}$; (c) $t=15.67 \mathrm{~s}$. (d) The dependence of the dendrite branches length $h_{1}, h_{2}, h_{3}$ on time t. (e) The dependence of the area $\mathrm{S}$ of the crystalline phase on time $t$.

$10.77 \mathrm{~s}$; (c) $t=15.67 \mathrm{~s}$. The dependence of the length of the dendrite branch of the first order $h_{1}$ and of the second order $h_{2}$ and $h_{3}$ on time $t$ is shown in Fig. 8d.
The increase of $h_{1}, h_{2}$ and $h_{3}$ occurs at a constant rate $v_{1}=0.064 \mu \mathrm{s}^{-1}, \nu_{2}=0.041 \mu \mathrm{s}^{-1}$, $v_{3}=0.040 \mu \mathrm{s}^{-1}$, respectively. The ratio $v_{1}>$ $v_{2}>v_{3}$ shows, that the dendrite branches of 
the first order grow faster than all. The later the branch appeared, the more slowly it grows.

Fig. 8e shows the quadratic dependence of the area $S$ of the crystalline phase on time: $S(t)=0.007 \cdot t^{2}\left(\mu \mathrm{m}^{2}\right)$. The area of the analyzed sample $S_{s}=2.65 \mu \mathrm{m}^{2}$. So, characteristic time $t_{0}=15.5 \mathrm{~s}$ and characteristic length $D_{0} \approx 2 v_{1} t_{0} \approx 2.0 \mu \mathrm{m}$. Various branches of dendrites of $\mathrm{HfO}_{2}$ have different crystallographic orientations. Therefore, the relative length of crystallization $\delta_{0}$ should be defined as (2), where the volume of the unit cell of the monoclinic modification of $\mathrm{HfO}_{2} \Omega=1.3828 \cdot 10^{-10} \mu \mathrm{m}^{3}$. According (2) for dendrite polymorphous crystallization of $\mathrm{HfO}_{2}$ the relative length $\delta_{0}=3868$.

\section{Conclusions}

The generality of the processes of crystal growth from the vapor phase and from the amorphous state is that in both cases a disorder-order transition takes place. This predetermines the structural and morphological analogy (Table) between the main forms of crystal growth on substrates (FM, VW and SK growth mode) and the main types of crystallization of amorphous films (LPC, IPC and DPC).

Frank-van der Merwe growth mode corresponds to the type of layer polymorphous crystallization, since in both cases a singlecrystal layer is formed. In the case of LPC of $\mathrm{Cr}_{2} \mathrm{O}_{3}$ under the action of an electron beam, crystals with different morphologies (disk-shaped, sickle-shaped and needleshaped crystals) can originate in amorphous film, each of which has its kinetics of development. At a fixed density of the electron beam through the film disk-shaped crystals grow with a constant speed, unchanged morphology for with $x(t) \sim t^{2}$ and $\delta_{0} \sim 3200$. Sickle-shaped crystals grow with a variable rate and with a changeable morphology: with increasing of the crystalline fraction $x$, the sickle-shaped crystal takes the form of a ring and further the form of a disk. After it crystal grows with constant speed and unchanged morphology. Before the appearance of lateral branches, the needleshaped crystal grows with a constant speed and with unchanged morphology.

Volmer-Weber growth mode corresponds to the type of island polymorphous crystallization, since in both cases a polycrystalline layer is formed. In the case of IPC of $\mathrm{ZrO}_{2}$ average diameter of crystals $\langle D>\sim t$, $x(t)$ is described by the exponential relation and $\delta_{0} \approx 800$.
Implementation of Stranski-Krastanov growth mode somewhat analogous to the type of dendrite polymorphous crystallization, since in both cases the surface of a single-crystal layer serves as the site for the formation of branches with a different shape and orientation. In the case of DPC of $\mathrm{HfO}_{2}$ single crystals in the form of dendrite branches of the first order are the place of formation of branches of the second and third order. Branches are formed from a number of randomly oriented crystals in the process of geometric selection $[19,20]$. The length of the dendrite branches $h \sim t$, the fraction of the crystalline phase $x \sim t^{2}$ and the relative length $\delta_{0} \sim 3900$. It should also be considered as a manifestation of SK growth mode the formation of lateral branches at growth of needle-shaped crystals in amorphous films of $\mathrm{Cr}_{2} \mathrm{O}_{3}$.

\section{References}

1. E.Bauer, Zeitschrift fur Kristallographie, 110, 372 (1958).

2. E.Bauer, H.Poppa, Thin Solid Films, 12, 167 (1972).

3. G.Le Lay, R.Kern, J.Cryst.Growth, 44, 197 (1978).

4. A.Chernov, Modern Crystallography III. Crystal Growth, Springer, Berlin (1984).

5. A.Bagmut, Tech. Phys. Lett., 38, 488 (2012).

6. A.G.Bagmut, Electron Microscopy of Films Deposited by Laser Evaporation, Monograph NTU "KhPI", Kharkiv, 2014 [in Russian].

7. A.G.Bagmut, V.M.Beresnev, Phys. Solid State, 59, 151 (2017).

8. A.G.Bagmut, Phys. Solid State, 59, 1225 (2017).

9. A.Bagmut, J.Cryst. Growth, 492, 92 (2018).

10. I.Bolotov, V.Kolosov, A.Kozhyn, Phys. Status Solidi A, 72, 645 (1982).

11. V.Kolosov, L.Veretennikov, Surf. Invest., 16, 361 (2001).

12. A.Bagmut, J.Surf. Invest. X-ray, Synchrotron and Neutron Techn., 7, 884 (2013).

13. A.Bagmut, S.Grigorov, V.Kolosov et al., Functional Materials, 10, 687 (2003).

14. A.Bagmut, V.Zhuchkov, V.Kolosov et al., Cryst. Rep., 51, S150 (2006).

15. V.Kolosov, A.Tholen, Acta Mater., 48, 1829 (2000).

16. A.Bagmut, J.Adv.Microsc. Res., $\quad 13, \quad 376$ (2018).

17. G.Ruitenberg, A.Petford-Long, R.Doole, $J$. Appl.Phys., 92, 3116 (2002).

18. S.Zharkov, L.Kveglis, Phys. Solid State, 46, 969 (2004).

19. G.Laemmlein, Dokl.Akad.Nauk SSSR, 48, 177 (1945).

20. A.Shtukenberg, Yu.Punin, E.Gunn, B.Kahr, Chem. Rev., 112, 1805 (2012). 